\title{
Expression of auxin carrier genes during adventitious rooting in Eucalyptus globulus
}

\author{
Arthur Fett-Neto ${ }^{*}$, Marcia De Almeida, Carolina Ruedell \\ From IUFRO Tree Biotechnology Conference 2011: From Genomes to Integration and Delivery \\ Arraial d'Ajuda, Bahia, Brazil. 26 June - 2 July 2011
}

\begin{abstract}
Background
Eucalyptus globulus and its hybrids are important for the cellulose and paper industry, mainly due to their relatively low lignin content. However, rooting of cuttings of this species is often recalcitrant and exogenous auxin application is necessary for adventitious root development. Auxin plays a central role in rooting capacity, which is particularly affected by its endogenous content and transport rate. The shoot apex is a major source of endogenous auxin, which is mainly transported by both influx (AUX1) and efflux (PIN) carriers in a specific basipetal active transport through the vascular parenchyma in stems. As part of a larger study to investigate the causes of low rooting in E. globulus microcuttings without exogenous auxin, we evaluated the expression profiles of AUX1 andPIN1 during the process of adventitious rooting using $\mathrm{qPCR}$.
\end{abstract}

\section{Material and methods}

E. globulus in vitro tip microcuttings obtained from 14 week-old seedlings were submitted to a culture system consisting of a two-step protocol: an initial step of induction, which lasted $96 \mathrm{~h}$ (induction medium composition: $0.3 \mathrm{x}$ MS salt concentration, $0.4 \mathrm{mg} \mathrm{l}^{-1}$ thiamine $\mathrm{HCl}, 100$ $\mathrm{mg} \mathrm{l}^{-1}$ inositol, zero (control) or $10 \mathrm{mg} \mathrm{l}^{-1}$ indolyl-butyric acid (IBA - root promoting auxin), equivalent to 49.3 $\mu \mathrm{M}, 30 \mathrm{~g} \mathrm{l}^{-1}$ sucrose and $6 \mathrm{~g} \mathrm{l}^{-1}$ agar, followed by a formation step (same composition of induction medium, but devoid of auxin and supplemented with $1 \mathrm{~g} \mathrm{l}^{-1}$ activated charcoal). The expression analysis of the selected genes was monitored along the rooting process and the harvest of microcuttings for RNA extraction was done at 6,12 , 24,48 and $96 \mathrm{~h}$ of exposure to induction medium and 24 and $48 \mathrm{~h}$ after transfer to formation medium (formation

\footnotetext{
* Correspondence: fettneto@cbiot.ufrgs.br
Gabriela Pereira Center for Biotechnology, Federal University of Rio Grande

* Correspondence: fettneto@cbiot.ufrgs.br
Gabriela Pereira Center for Biotechnology, Federal University of Rio Grande do Sul, Porto Alegre, RS, Brazil
}

(c) 2011 Fett-Neto et al; licensee BioMed Central Ltd. This is an open access article distributed under the terms of the Creative Commons Attribution License (http://creativecommons.org/licenses/by/2.0), which permits unrestricted use, distribution, and reproduction in any medium, provided the original work is properly cited. step), for both treatments (with and without auxin in the tings remained for $96 \mathrm{~h}$ in the induction medium before transfer to formation medium. Total RNA was extracted, and the first strand cDNA synthesis was performed for all of the samples starting from about $500 \mathrm{ng}$ total RNA, using oligo-dT primers and reverse transcriptase M-MLV (Invitrogen) in a final volume of $20 \mu \mathrm{l}$. The final cDNA products were diluted 50-fold in RNAse-free distilled water prior to use in qPCR. The analysis was carried out using specific primers for Arabidopsis thaliana orthologue genes in eucalypt and both Histone $\mathrm{H} 2 \mathrm{~B}(\mathrm{H} 2 \mathrm{~B})$ and Alpha-Tubulin (TUA) genes were used as references [1]. The data were analysed with the comparative $\mathrm{Ct}$ method [2].

\section{Results and conclusion}

The gene encoding the auxin influx carrier $(A U X 1)$ did not show differences in expression profile between treatments (with and without exogenous auxin), suggesting that $A U X 1$ is not critical to the process of adventitious rooting promoted by exogenous auxins in microcuttings. This would be in line with the fact that the rate of endogenous auxin transport is probably not limiting under exogenous auxin supply. The auxin efflux carrier gene encoding PIN1 showed an expression increase during the first 24 hours of the induction step in microcuttings exposed to exogenous auxin when compared with the control treatment (without exogenous auxin supply). This result seems to indicate a requirement of PIN1 to redistribute and perhaps concentrate auxin, possibly IBA-derived IAA (indolyl-3-acetic acid), in specific areas of the base of microcuttings, in order to allow root development. Although IBA is a natural auxin recognized as an IAA precursor, its use as exogenous auxin instead of IAA, a common practice in clonal propagation by cuttings, may have also involved the 
expression of other sets of recently described IBA-specific transporters [3]. In conclusion, despite the unusual exogenous auxin entrance pathway into the microcutting compared to the endogenous auxin fluxes, PIN1 likely takes part in the process of auxin concentration required to program founder cells involved in the establishment of new root meristems.

\section{Acknowledgements}

Funding for this investigation was provided by the Brazilian agencies National Council for Scientific and Technological Development (CNPq) and Rio Grande do Sul State Foundation for Research Support (Fapergs).

Published: 13 September 2011

\section{References}

1. De Almeida MR, Ruedell CM, Ricachenevsky FK, Sperotto RA, Pasquali G, Fett-Neto AG: Reference gene selection for quantitative reverse transcription-polymerase chain reaction normalization during in vitro adventitious rooting in Eucalyptus globulus Labill. BMC Molecular Biology 2010, 11:73.

2. Livak KJ, Schmittgen TD: Analysis of relative gene expression data using real-time quantitative PCR and the 2- $\Delta \Delta C T$ method. Methods 2001, 25:402-408.

3. Strader LC, Bartel B: Transport and metabolism of the endogenous auxin precursor Indole-3-Butyric Acid. Molecular Plant 2011, 1-10.

doi:10.1186/1753-6561-5-S7-P64

Cite this article as: Fett-Neto et al.: Expression of auxin carrier genes

during adventitious rooting in Eucalyptus globulus. BMC Proceedings 2011 5(Suppl 7):P64.

\section{Submit your next manuscript to BioMed Central} and take full advantage of:

- Convenient online submission

- Thorough peer review

- No space constraints or color figure charges

- Immediate publication on acceptance

- Inclusion in PubMed, CAS, Scopus and Google Scholar

- Research which is freely available for redistribution

Submit your manuscript at www.biomedcentral.com/submit 